\title{
Conservation status of Caribbean coot Fulica caribaea in the Netherlands Antilles and other parts of the Caribbean
}

\author{
Vincent Nijman ${ }^{1,2, *}$, Mansour Aliabadian ${ }^{2}$, Adolphe O. Debrot ${ }^{3}$, John A. de Freitas ${ }^{3}$, \\ Laurens G. L. Gomes ${ }^{2}$, Tineke G. Prins ${ }^{2}$, Ronald Vonk ${ }^{2}$ \\ ${ }^{1}$ Department of Anthropology and Geography, School of Social Science and Law, Oxford Brookes University, \\ Oxford OX3 0BP, UK \\ ${ }^{2}$ Zoological Museum, University of Amsterdam, PO Box 94766, 1090 GT Amsterdam, The Netherlands \\ ${ }^{3}$ CARMABI Foundation, Piscaderabaai z/n, PO Box 2090, Willemstad, Curaçao, Netherlands Antilles
}

\begin{abstract}
In 2005 to 2006 we assessed the status of the Caribbean coot Fulica caribaea in the Netherlands Antilles, largely semi-arid islands in the South Caribbean, with small numbers of permanently available fresh water bodies. The Caribbean coot is a freshwater bird which is dependent on the seasonal availability of freshwater ponds for breeding; it breeds on 4 of the 6 islands of the Netherlands Antilles, viz. Curaçao (first recorded in 1956), Bonaire (1974), Aruba (1977), and St. Maarten (1981). Compared to the period up to and including 1979, group sizes in 1980 to 2006 were larger on Curaçao, and it appears more abundant in the latter period on all islands. We report on 49 sites (>5 ha) in the Caribbean where the species has been recorded, or where we would expect it to occur on the basis of available habitat. Threats to the Caribbean coot include drainage or reclamation of habitat, hunting, and pollution. Few sites receive protection. The coot has a restricted range of occupancy of some $1000 \mathrm{~km}^{2}$, spread out over 13 islands, representing 10 countries. Based on its restricted range, coupled with high levels of threat and the limited amount of protection, we recommend that the species be included as 'Vulnerable' in the IUCN (International Union for the Conservation of Nature and Natural Resources, World Conservation Union) Red List. An increase in the level of (legal) protection, in addition to an increase in the amount of habitat included in the regional protected areas network and heightening the awareness of the needs of this Caribbean endemic are overdue. The establishment of permanent freshwater ponds, especially in the arid parts of its range, appears favourable for the species, and may aid conservation.
\end{abstract}

KEY WORDS: Conservation status - Fulica americana - Hybridisation · Restricted-range species · Waterbirds

Resale or republication not permitted without written consent of the publisher

\section{INTRODUCTION}

The Caribbean coot Fulica caribaea is endemic to the chain of islands from the Southern Bahamas to Trinidad, with smaller numbers in northwest Venezuela and off-lying islands (Raffaele et al. 1998, Taylor 1996, Taylor \& van Perlo 1998). Within this region, it has been recorded in 21 countries, but in most of these as vagrant or as a non-breeding resident. Breeding has been confirmed on 13 islands, representing 10 countries (BirdLife International 2006, McNair \& CramerBurke 2006) (see Table 2 and Fig. 1). The conservation status of the Caribbean coot has always been somewhat obscured as it was formerly considered conspecific with the American coot F. americana (e.g. Voous 1983), a species that breeds at northern latitudes, but that winters in large numbers in the Caribbean. Currently the species is considered 'Near Threatened' 
according to IUCN threat criteria as it has suffered a marked decline throughout the Caribbean as a result of hunting pressure, egg collection, habitat loss and introduced predators (BirdLife International 2006). On most of the islands within its range the Caribbean coot is uncommon to rare, and in parts of its range, e.g. St. Kitts and Nevis, and Barbados, it has disappeared as a breeding bird (although in Barbados it has recently been confirmed breeding after an absence of almost 100 yr; Frost \& Massiah 2001).

There are marked climatic differences within the Caribbean; the southern part can be characterised as semi-arid with few permanent freshwater sources available, whereas rainfall is more plentiful in the northwest (Raffaele et al. 1998, H. Hulsman et al. unpubl.). In the less arid parts of its range the coot is largely dependent on freshwater lakes, ponds, marshes, and, less frequently, coastal brackish lagoons. In the more arid parts, the coot is an eruptive and irregular breeder, and is not present year-round (Voous 1983), although increasingly it makes use of permanent man-made ponds at e.g. golf courses and wastewater treatment plants (Prins et al. 2005).

Here we assess the conservation status of the Caribbean coot in the Netherlands Antilles. This group of islands is one of the few in the Caribbean for which detailed quantitative ornithological data are available from the 1930s onwards (Prins \& Nijman 2005). We quantify changes that have occurred over time by comparing recorded group sizes. With knowledge on the biology of the species from the Netherlands Antilles (Prins et al. 2005), and also other parts of its range, we estimate its range of occupancy in the Caribbean, and assess the species' conservation status.

\section{MATERIALS AND METHODS}

Status assessment in the Netherlands Antilles. The Netherlands Antilles and Aruba (Fig. 1) comprises 6 islands, and 2 islets; the Caribbean coot has been confirmed on 4 islands (Aruba, Curaçao, Bonaire, and St. Maarten). In August to September 2005 and July 2006 we conducted fieldwork on the first 3 islands (and the islet of Klein Bonaire), visiting essentially all freshwater and coastal brackish lagoons. We recorded group sizes for each lake or lagoon, and gave total numbers for each island. Caribbean coot appear to have become more common on these islands in recent years, and in order to quantify these temporal changes, we compared the data collected by us, other birders and ornithologists from the period 1980 to 2006 (n = 57 ), with those collected likewise by other birders and ornithologists in the period 1938 to 1979 ( $\mathrm{n}=78$ ) as deposited in the archives of the Zoological Museum, Amsterdam, The Netherlands. The cut-off line be-

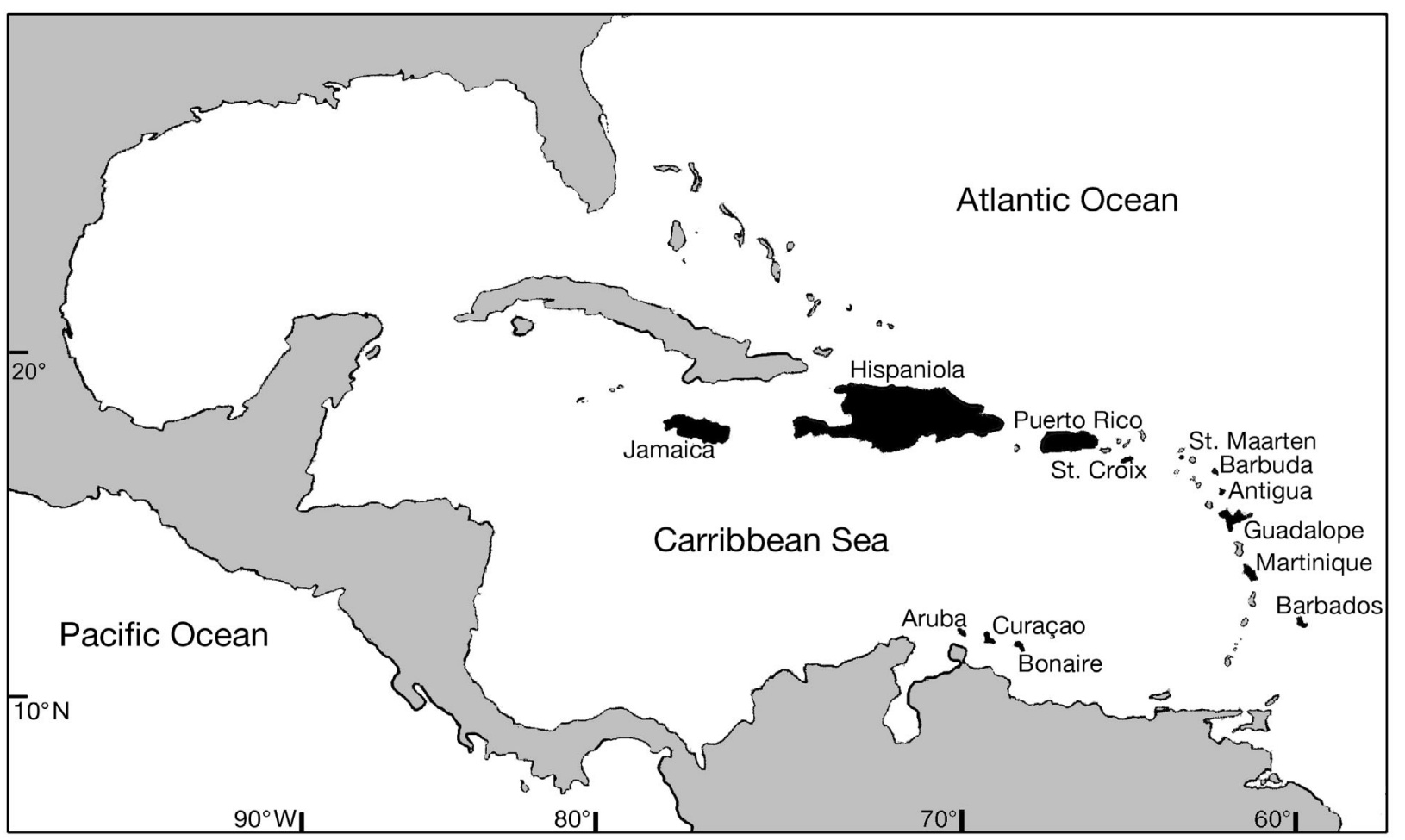

Fig. 1. Fulica caribaea. Breeding range of the Caribbean coot showing all islands (black) where the species has been confirmed breeding 
tween these 2 periods (1980) was chosen somewhat arbitrarily but roughly coincides with the transition of the islands from a rural-industrial economy to one based largely on tourism (Prins \& Nijman 2005).

Global status assessment. Observations elsewhere (Voous 1983, Taylor \& van Perlo 1996, Raffaele et al. 1998, Frost \& Massiah 2006, McNair \& Cramer-Burke 2006), together with our own observations, indicate that the Caribbean coot is largely dependent for breeding on lakes, ponds, marshes, and, albeit less frequently, coastal brackish lagoons. We aimed to assess the species' range of occupancy, by summation of the total wetland areas in the 10 countries where the species has been confirmed breeding. As a starting point, for each island, we used the Directory of Neotropical Wetlands (Scott \& Carbonell 1986), and searched for wetlands where either Caribbean coot had been recorded, or which, based on the description of the habitat, were likely to hold Caribbean coot. On 1 site (Southgate Pond, St. Croix, US Virgin Islands) in addition to pure Caribbean coots, mixed pairs of Caribbean coot and American coot have also been recorded (McNair \& Cramer-Burke 2006), and this site is included in our analysis. Secondly, we searched the internet (including the Global Biodiversity Information Facility website [www.gbif.org] which lists data from participating zoological collections) for affirmative records of Caribbean coot in each of the 10 countries, mostly by checking birding reports. This often resulted in the confirmation of the presence of the species in areas listed in the Neotropical Wetlands database. Sites with an estimated area of $<5$ ha were excluded. From the database, as well as from the bird reports, we made a qualitative assessment of the threats faced by the Caribbean coot.

\section{RESULTS}

\section{Netherlands Antilles}

Breeding in Curaçao was first recorded in 1956, in Bonaire in 1974, in Aruba in 1977, and in St. Maarten as recently as 1981. Although the Caribbean coot may have bred on the islands prior to these dates, intensive ornithological explorations particularly on the first 3 islands (summarised in Voous 1982, 1983, 1985) did not find any evidence of earlier breeding activity. For this reason we believe that the recent recorded increase in breeding activities is genuine.

There are significant differences in group sizes found on the 4 islands (Kruskall-Wallis 1-way analysis of variance, $H=11.7, \mathrm{df}=3, \mathrm{p}=0.009$ and $H=$ 10.8 , df $=3, p=0.01$, for the pre-1980 and post-1980 period, respectively; Table 1). On 3 out of 4 islands the average group size has increased over time; however, the difference is only significant for Curaçao. On all 4 islands the number of sites has seen a temporal increase, and currently the species is known from 19 ponds, lakes, and reservoirs. Some of these are very small, i.e. less than 5 ha, and sometimes even less than $1 \mathrm{ha}$, and breeding is not confirmed from all sites.

\section{Global status}

We compiled data from 49 sites where the Caribbean coot is known to occur ( $\mathrm{n}=28)$, or where, based on the available habitat and the fact that the species is known to breed locally, it is suspected to occur $(\mathrm{n}=21)$ (Table 2). Most of the sites where the Caribbean coot has been recorded are small, with only 15 areas covering $>1000 \mathrm{ha}$. The total area of these sites is some $1000 \mathrm{~km}^{2}$.

Legal protection is limited; only 11 sites are included in the regional protected area network, and at an additional 5 sites the species receives some partial protection (mostly in the form of restrictions imposed on hunters). Some sites are privately owned and the coots present at these sites may or may not be adequately protected.

Despite some sites receiving legal protection, all but a few sites are threatened. The most common threats are drainage or land reclamation (19 sites), hunting (17 sites), and pollution (10 sites), and at many sites the Caribbean coots face multiple threats, despite 'protection'.

Table 1. Fulica caribaea. Group sizes of Caribbean coot (mean $\pm \mathrm{SD}$ ), and number of sites where the species was recorded in the Netherlands Antilles. n: no. of groups recorded; range: minimum and maximum group sizes recorded. p-values refer to Mann-Whitney $U$-tests on group sizes between the 2 periods

\begin{tabular}{|c|c|c|c|c|c|c|c|c|c|}
\hline \multirow{2}{*}{ Island } & \multicolumn{4}{|c|}{ — Pre-1980 (1938-1979) } & \multicolumn{4}{|c|}{ — Post-1980 (1980-2006) } & \multirow[t]{2}{*}{$\mathrm{p}$} \\
\hline & Mean \pm SD & $\mathrm{n}$ & Range & No. of sites & Mean \pm SD & $\mathrm{n}$ & Range & No. of sites & \\
\hline Aruba & $4.5 \pm 4.5$ & 28 & $1-20$ & 2 & $8.8 \pm 12.6$ & 10 & $2-40$ & 3 & 0.40 \\
\hline Curaçao & $21.2 \pm 52.4$ & 18 & $1-170$ & 3 & $109.3 \pm 215.7$ & 16 & $3-800$ & 6 & 0.001 \\
\hline Bonaire & $24.8 \pm 41.4$ & 26 & $1-200$ & 4 & $13.8 \pm 18.7$ & 32 & $1-40$ & 7 & 0.33 \\
\hline St Maarten & $8.3 \pm 7.5$ & 5 & $1-18$ & 1 & $4.3 \pm 2.4$ & 6 & $1-7$ & 3 & 0.93 \\
\hline
\end{tabular}




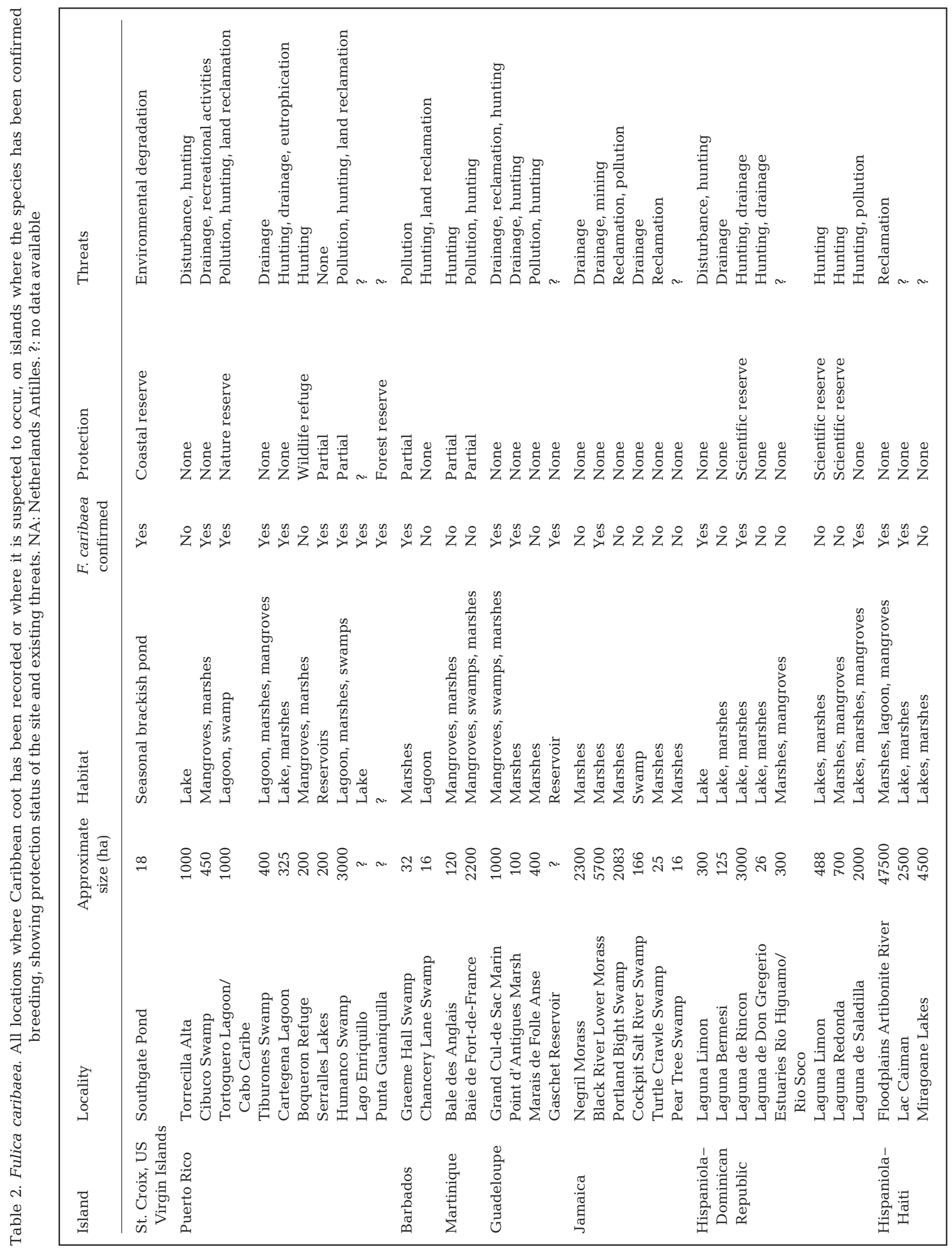




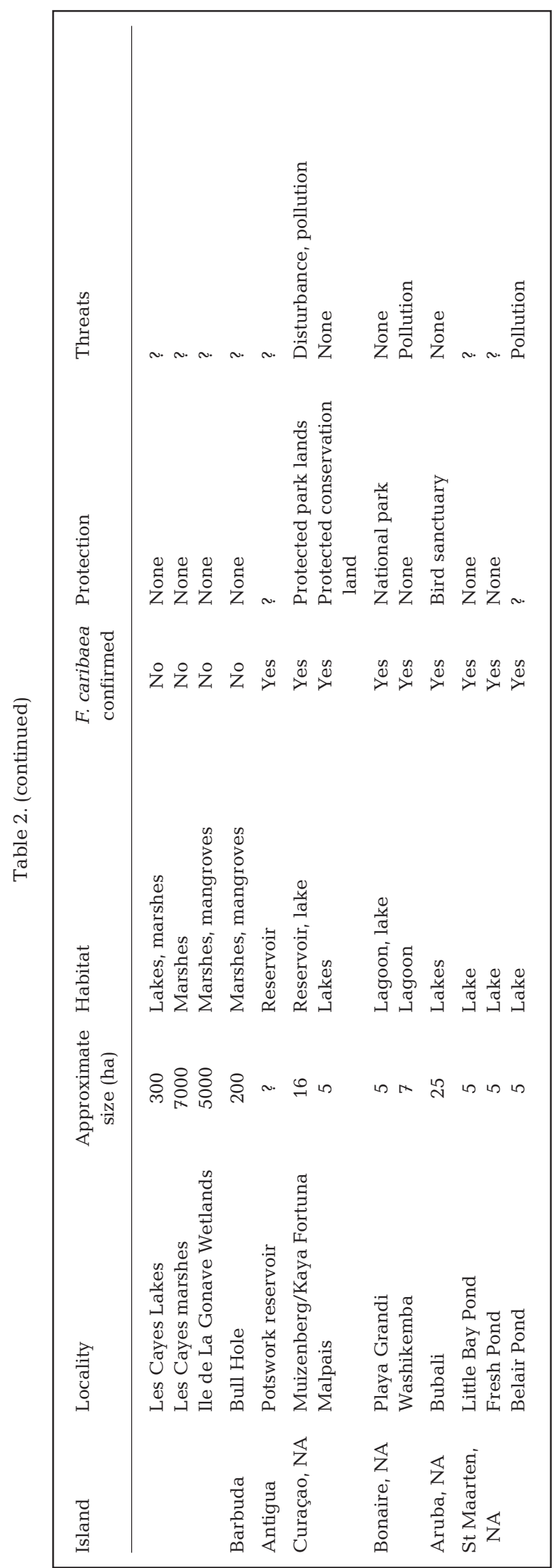

\section{DISCUSSION}

\section{Status in the Netherlands Antilles}

We documented an increase in number of sites, and, at least for Curaçao, a significant increase in group sizes (and hence overall numbers) of Caribbean coot in 4 of the 6 islands of the Netherlands Antilles. Confirmed cases of breeding on these islands are mostly recent, and overall, there is a clear indication that the Caribbean coot has expanded its range in the Netherlands Antilles. Although the total area of occurrence on these islands is small and the species is not protected by law, the species seems not to be threatened by hunting or egg-collection, and as such the situation here fares well compared to other parts of the species' range (cf. Prins \& Nijman 2005). The observed increase is mostly due to an increase in the number of permanently available freshwater ponds, in part as a means of accommodating the needs of the increased number of tourists. Better maintenance of dams allows ponds to retain water even during dry years, and newly created ponds (on golf courses, water treatment plants) increase the available habitat. In addition, a general increase in environmental awareness on the islands may allow for better protection of the Caribbean coot.

\section{IUCN threat status and conservation implications}

The total area of the 49 sites where Caribbean coot is known or expected to occur is some $1000 \mathrm{~km}^{2}$, but the amount of suitable habitat must be smaller. Although small areas ( $<5$ ha) are not included in Table 2, and in this way we may be potentially underestimating the species' range of occupancy, this is more than counterbalanced by the fact that particularly some of the larger areas listed are covered only in part with suitable habitat. Furthermore, for many sites there are few or no records of Caribbean coot, suggesting poor coverage by ornithologists, or presence of coots being restricted to certain years or to certain parts of the year only, or both.

We have shown that the Caribbean coot has a restricted range of occupancy in the order of $1000 \mathrm{~km}^{2}$, spread out over 13 islands. Even if we account for additional sites not included in our estimate, given that most of the sites where it has been recorded thus far cover a small area only, it is unlikely that the species' range of occupancy is significantly larger than our estimate. Within this limited range, the species receives a limited amount of protection, and at most sites where the species has been recorded it faces direct or indirect threats.

BirdLife International (2006) considered that the Caribbean coot nearly qualified for listing as threat- 
ened under IUCN Criteria A2cde, i.e. an observed, estimated, inferred or suspected population size reduction of $\geq 30 \%$ over the last $10 \mathrm{yr}$, where the reduction or its causes may not have ceased or may not be understood or may not be reversible, based on a decline in area of occupancy, extent of occurrence and/or quality of habitat, actual or potential levels of exploitation and the effects of introduced taxa, hybridization, pathogens, pollutants, competitors or parasites.

We were not able to quantify this reduction, but we argue that the species faces a high risk of extinction in the wild based on the limited area of occupancy coupled with continuing threats and limited effective protection. With a range of occupancy $<2000 \mathrm{~km}^{2}$, that is severely fragmented, and an inferred or projected decline in the area of occupancy, the area, extent and quality of its habitat, and the number of mature individuals, the species meet the IUCN Criteria for listing as 'Vulnerable' (B2ab, ii-iii-v).

In order to increase the survival changes of the Caribbean coot, both the species itself and its habitat need more active protection. The species is best served by improved legal protection within the countries of its range (sustained by effective enforcement), which would aim, for example, to reduce the number of birds killed by hunters, as well as the numbers of eggs collected by egg-collectors. Protection of habitat is best achieved by an increase in the amount of habitat included in the protected area network (again coupled with active hands-on protection). Thus far, most countries within the range of the species have invested heavily in protecting the marine environment, omitting much needed protection of terrestrial species.

Hybridisation is relatively uncommon in Gruiformes (Aliabadian \& Nijman 2007), but there are reported cases of mixed pairing between Caribbean coot and American coot from islands where the species is rare (Voous 1983, McNair \& Cramer-Burke 2006). This low number of reported cases of mixed pairing may suggest that hybridisation poses a low threat to the Caribbean coot, although this requires urgent further research. We hope that our analysis will draw the attention of both local communities and governments and national and international conservation NGOs operating in the region to the plight of the Caribbean coot, as well as other freshwater species in this region.

Acknowledgements. We thank the late Prof. Karel H. Voous (Zoological Museum Amsterdam) for sharing his knowledge

Editorial responsibility: Brendan Godley (Editor-in-Chief), University of Exeter, Cornwall Campus, UK on the birds of the Netherlands Antilles and for providing information on the species' status in past decades. Kees Roselaar is thanked for providing information on Caribbean coots. Richard Inger and an anonymous reviewer are thanked for comments on the manuscript. Our research in the Netherlands Antilles is funded by grants from BirdLife Netherlands (Vogelbescherming), The Netherlands Organisation for Scientific Research (NWO: Contract number R84-641), Amsterdamse Universiteitsvereniging, Schuurman-Schimmel-van Outeren Fonds and Martina de Beukelaar / J. C. van der Hucht Fonds.

\section{LITERATURE CITED}

Aliabadian M, Nijman V (2007) Avian hybridisation: incidence and geographic distribution of hybridisation in birds. Contrib Zool 76:59-61

BirdLife International (2006) Species factsheet: Fulica caribaea. Available at: www.birdlife.org/datazone/search/ species_search.html?action=SpcHTMDetails.asp\&sid $=2947 \& \mathrm{~m}=0$ (accessed on 18 December, 2006)

Frost MD, Massiah EB (2001) Caribbean coot (Fulica caribaea) - the return of a former breeding resident bird. J Barbados Mus Hist Soc 47:85-89

McNair DB, Cramer-Burke C (2006) Breeding ecology of American and Caribbean coots at Southgate Pond, St. Croix: use of woody vegetation. Wilson J Ornithol 118:208-217

Prins TG, Nijman V (2005) Historic changes in status of Caribbean coot in the Netherlands Antilles. Oryx 39:125-126

Prins TG, Roselaar K, Nijman V (2005) Status and breeding of Caribbean coot in the Netherlands Antilles. Waterbirds 28:146-149

Raffaele H, Wiley J, Garrido O, Keith A, Raffaele J (1998) Birds of the West Indies. Christopher Helm Identification Guides, A \& C Black, London

Scott DA, Carbonell M (1986) A directory of neotropical wetlands. International Union for the Conservation of Nature and Natural Resources (IUCN), Cambridge, and International Waterfowl and Wetland Research Bureau, Slimbridge

Taylor PB (1996) Family Rallidae (rails, gallinules and coots). In: del Hoyo J, Elliott A, Sargatal J (eds) Handbook of the birds of the world, Vol 3 Hoatzin to Auks. Lynx Edicions, Barcelona, p 108-209

Taylor PB, van Perlo B (1998) Rails. A guide to the rails, crakes, gallinules and coots of the world. Pica Press, Tonbridge

Voous KH (1982) Straggling to islands - South American birds in the islands of Aruba, Curaçao, and Bonaire, South Caribbean. J Yamashina Inst Ornithol 14:171-178

Voous KH (1983) Birds of the Netherlands Antilles. De Walburg Pers, Zutphen

Voous KH (1985) Additions to the avifauna of Aruba, Curaçao, and Bonaire, South Caribbean. In: Buckley PA, Foster MS, Morton ES, Ridgely RS, Buckley FG (eds) Neotropical ornithology (Ornithological Monographs 36). American Ornithologists' Union, Washington, DC, p 247-254

Submitted: August 6, 2007; Accepted: November 5, 2007 Proofs received from author(s): December 20, 2007 